\title{
Thaliacean distribution and abundance in the northern part of the Levantine Sea (Crete and Cyprus) during the eastern Mediterranean climatic transient, and a comparison with the western Mediterranean basin
}

\author{
Horst Weikert · Jean E. A. Godeaux
}

Received: 23 January 2008 / Revised: 25 July 2008 / Accepted: 28 July 2008 / Published online: 26 August 2008

(C) Springer-Verlag and AWI 2008

\begin{abstract}
First results are presented on the composition, abundance and vertical distribution of the thaliacean fauna in the Levantine basin obtained from stratified tows at three deep-sea sites in 1993: SE off Crete, and SW and NE off Cyprus. Samples with a $10 \mathrm{~m}^{2}$-MOCNESS (mesh size $1.67 \mathrm{~mm}$ ) were poor in species and specimens as compared to samples with a $1 \mathrm{~m}^{2}$-double-MOCNESS $(0.333 \mathrm{~mm})$. Of the 12 species identified, six species belonged to the most abundant Doliolida, predominated by the phorozooids of Doliolum nationalis, five species belonged to the Salpida and one to the Pyrosomatida. Thaliaceans, most abundant by species and numbers SE off Crete, comprised $\leq 0.2 \%$ of the local mesozooplankton standing stocks. Presumably, they did not contribute substantially to the vertical flux generating the locally increased biomass and activity of the microbial benthos at the 4,300 m deep Cretean site. Most doliolids and salps were collected from the epipelagic and upper mesopelagic layers, and appeared to be most abundant close to the deep maximum of chlorophyll- $a$. Samples below $150 \mathrm{~m}$ were rarely rich in specimens, although two species performed diel migrations from the mesopelagic zone into the surface layers where some vertical segregation was evidenced. The aspect of niche separation is discussed.
\end{abstract}

Communicated by H.-D. Franke.

H. Weikert $(\bowtie)$

Institut für Hydrobiologie und Fischereiwissenschaft,

Universität Hamburg, Gr. Elbstr. 133,

22767 Hamburg, Germany

e-mail: weikert@uni-hamburg.de

J. E. A. Godeaux

Institut de Zoologie, Biologie Marine,

Université de Liège, 4020 Liège, Belgium
Keywords Thaliacea - Eastern Mediterranean Sea . Levantine Sea - Composition - Regional abundance . Vertical distribution

\section{Introduction}

Thaliaceans are widespread in the world's oceans, with a preference for tropical and warm temperate waters, except a few species only present south of $50^{\circ} \mathrm{S}$ (Kashkina 1978; Deibel 1998; van Soest 1998). By virtue of their rapid asexual reproduction (Gibson and Paffenhöfer 2002), they are able to form extensive swarms (Andersen 1998; Deibel 1998; and references therein) with up to tens of thousands of specimens per cubic metre (Deevey 1971), which can affect the trophodynamics in surface waters hampering markedly the development of other zooplankton (Berner 1967; Aldredge and Madin 1982) by the reduction of phytoplankton (Deibel 1982, 1985, 1998; Dubischar and Bathmann 1997). Like in other seas, in the western Mediterranean (CIESM 2001) thaliaceans can thus locally comprise an exceeding portion of the surface zooplankton standing stock in terms of numbers and biomass. By their capability of exploiting small particles over a wide size range, from bacteria to large diatoms and microzooplankton (Silver and Bruland 1992; Caron et al. 1989; Kremer and Madin 1992) and repacking them into large fast-sinking faecal pellets within a resistant peritrophic membrane, thaliaceans contribute substantially to the rapid transfer of energy into deep waters (see Andersen 1998; Deibel 1998; and references therein), in addition to the mass sinking of individual corpses (Wiebe et al. 1979). It has been estimated that in the northwestern Mediterranean up to 74\% of the total primary production can be removed by salp blooms from the surface waters (Andersen 1998) which can 
enhance the process of carbon sequestration in the sea's interior-an aspect which is not only of intrinsic biological interest but also relevant to the potential use of the ocean as a carbon repository (Schrope 2007).

Different to the western Mediterranean Sea, thaliacean blooms have not been reported from the eastern Mediterranean which is one of the most oligotrophic water bodies (Redfield et al. 1963; Dugdale and Wilkerson 1988). The only sub-basin wide study on the abundance of thaliaceans is from the Ionian Sea where doliolids and salps accounted for $<2 \%$ of the zooplankton (Greze 1963).

Data from the Levantine Sea are of taxonomical concern, documenting a diversified thaliacean fauna (Godeaux 1999). Hydrographically, the strong variability of the surface water circulation on different scales (Özsoy et al. 1989) can return nutrients to the exhausted surface water and thereby boost a local phytoplankton bloom (Salihoglu et al. 1990; Krom et al. 1992; Ediger et al. 2005) which may be considered a general prerequisite for a flourishing thaliacean population (e.g. Wiebe et al. 1979; Deibel 1985; Morris et al. 1988). No information, however, is available as to which extent thaliaceans are involved in the observed increase of zooplankton (Salihoglu et al. 1990; SiokouFrangou et al. 1999).

In 1993, an outstanding increase of zooplankton throughout the water column was reported from a 4,200 m deep site SE off Crete and SW off Cyprus (Elwers 1995; Weikert 1995), which may be attributed (Weikert et al. 2001) to an upward shift of the nutricline in the course of the eastern Mediterranean transient, EMT (Klein et al. 1999). Although the thaliacean population was small relative to other taxa, we present the data on the populations of species and their ontogenetic stages, with a focus on regional abundance and vertical distribution, in order to provide basic information for the evaluation of the yet unknown role of thaliaceans in the Levantine Sea ecosystem.

\section{Material and methods}

Thaliaceans were obtained from zooplankton and micronekton samples collected during METEOR cruises 25, leg 2, between 11 and 26 June 1993 (Weikert 1994). Three areas were investigated by full depth profiles: the IerapetraDeep SE off Crete (site A) at $34^{\circ} 16^{\prime} \mathrm{N} / 25^{\circ} 46^{\prime} \mathrm{E}$, and one site each SW off Cyprus (B) at $34^{\circ} 05^{\prime} \mathrm{N} / 31^{\circ} 47^{\prime} \mathrm{E}$ and NE off Cyprus (C) at $35^{\circ} 30^{\prime} \mathrm{N} / 35^{\circ} 00^{\prime} \mathrm{E}$ (Fig. 1). The respective depths of sounding were 4,300, 2,700 and 1,200 m.

Two types of opening/closing devices were used at each site for oblique stratified sampling of the water column at a towing speed of about two knots through the water: a $1 \mathrm{~m}^{2}$ double-MOCNESS (D-MOC) equipped with 18 nets of $0.333 \mathrm{~mm}$ mesh size, and a $10 \mathrm{~m}^{2}$-MOCNESS (MOC10)

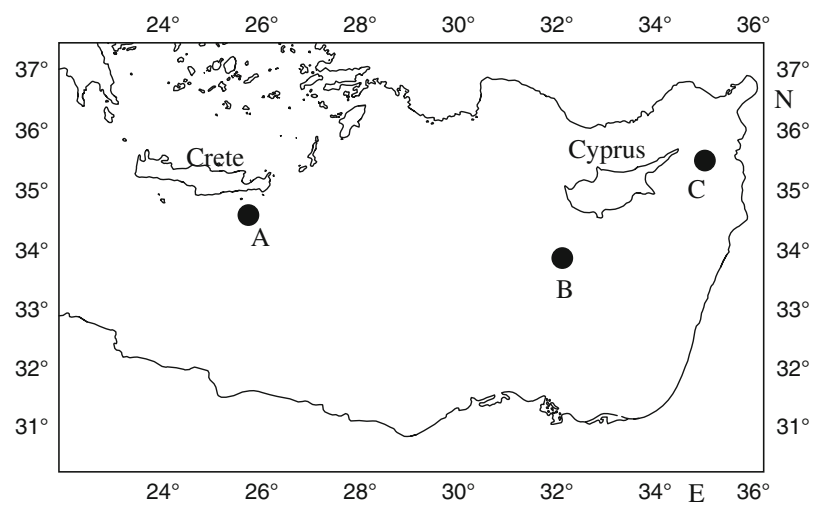

Fig. 1 Sampling sites in the Levantine Sea, June 1993

fitted with five $1.670 \mathrm{~mm}$ mesh nets, all nets dark stained (Wiebe et al. 1985). Both devices carried SeaBird CTD probes and sensors to measure flow past the net and net frame angle. We almost exclusively present the findings with the D-MOC, since the number of samples with the MOC10 was small and less specimens and species were collected in general: While the standing stocks of Salpa fusiformis, Thalia democratica and Thalia orientalis were in the same order of magnitude at site A (Mann-Whitney $U$-test, $P>0.05 ; n: 7 ; 2$ ), they were missing in the MOC10 samples off Cyprus except a few specimens of $T$. democratica at site C. Other species (Dolioletta gegenbauri, Doliolina muelleri, Pyrosoma atlanticum), if present in the MOC 10 , were collected in only scattered numbers at the sites.

Thaliaceans were collected from the upper $1,050 \mathrm{~m}$, yet chiefly in the upper $450 \mathrm{~m}$. Within the latter range $50 \mathrm{~m}$ intervals were fished with the D-MOC per haul between 425 and $25 \mathrm{~m}$, in addition to the top $25 \mathrm{~m}$. Off site $\mathrm{C}$, the uppermost layer was $0-35 \mathrm{~m}$, due to an offset of the pressure meter and the depth ranges of the $50 \mathrm{~m}$-intervals had changed accordingly.

The mean water volume filtered at the $50 \mathrm{~m}$-intervals was $332 \mathrm{~m}^{3}\left(\mathrm{SD} \pm 105 \mathrm{~m}^{3}\right)$ at the sites $\mathrm{A}$ and $\mathrm{B}$ and $300 \mathrm{~m}^{3}\left(\mathrm{SD} \pm 78 \mathrm{~m}^{3}\right)$ at site $\mathrm{C}$. This is about double as high as the mean filtered in the respective uppermost 25 or $35 \mathrm{~m}\left(\mathrm{~A} 146 \pm 44 \mathrm{~m}^{3}, \mathrm{~B} 172 \pm 18 \mathrm{~m}^{3}, \mathrm{C} 156 \pm 38 \mathrm{~m}^{3}\right)$. In total, five day-time and four night-time profiles were available from site $\mathrm{A}$, and two day and two night samples each from sites B and C.

Upon retrieval samples were preserved immediately in a $4 \%$ formaldehyde solution buffered with sodium tetraborate and transferred without delay into Steedman's preserving fluid (Steedman 1976) in the homelab prior to subsequent numerical sorting for major taxa and further storage. Samples of the D-MOC were split according to Kott (1953), unless the sample yielded less than 30 thaliaceans. 
The species were identified according to Godeaux (1998). Among the species, D. muelleri and Doliolina krohni display virtually identical stages (cryptic species: Godeaux 1961, 1998) except for the blastozooid stages (phorozooid and gonozooid). But even their species-specific determination is cumbersome. Therefore, the specimens of a rich sample at site A were not discriminated.

The individual numbers were standardized to $1,000 \mathrm{~m}^{3}$ (term "abundance") or $\mathrm{m}^{2}$ (integrals over the upper $1,050 \mathrm{~m}$, "standing stock") based on volume estimates of filtered water by a calibrated flowmeter, corrected for the net frame angle and the angle of the oblique haul through the water (H.W.). Counts from a day-time haul at site A which encompassed only the deepest layers of regular occurrence of species were accepted for $S$. fusiformis and $P$. atlanticum, because it fully covered the species' daytime residence depth, whereas the night-time counterpart was omitted. The weighted mean depth (WMD) of species was calculated as

$\mathrm{WMD}=\sum(n i \times d i) / \sum n i$

where $d i$ is the depth of a sample $i$ (defined as the midpoint of the depth interval), and $n i$ is the number of individuals $1,000 \mathrm{~m}^{-3}$ in this layer.

The environmental setting at the sites (Fig. 1) as defined by hydrography and phytoplankton distribution is well described (Lenz et al. 1994; Yilmaz et al. 1994; Detmer 1995). At all three sites the upper $50 \mathrm{~m}$ of the water column were strongly stratified as examplified for the site off Crete (Fig. 2). Here, the mixed layer was shallow (4-8 m) with an increase of particles with depth (up to $19 \times 10^{5}$ particles per $\mathrm{ml}$ ), whereas it was about $20-30 \mathrm{~m}$ deep at either site off Cyprus. Temperature was $>21^{\circ} \mathrm{C}$ in general, showing maximum values with $>24^{\circ} \mathrm{C}$ off Cyprus, and salinity increased from $38.73-38.83$ off Crete to 38.89 38.99 off Cyprus. Below the thermohalocline, the water was less than $16^{\circ} \mathrm{C}$ and salinity varied between 38.6638.77 off Crete and 38.84-38.90 off Cyprus.

The depth of the deep chlorophyll maximum (DCM) approximated or was near the bottom of the euphotic zone. The highest concentrations of $0.4-0.67 \mu \mathrm{g}$ Chl $a / 1$, surpassing background concentrations by an order of magnitude in the upper $150 \mathrm{~m}$, occurred off Crete between 60 and $90 \mathrm{~m}$ (Fig. 3), off Cyprus at $90 \mathrm{~m}$ (NE) and at $100 \mathrm{~m}$ (SW). The basis of the DCM was at $40 \mathrm{~m}$ off Crete and at 50-60 m off Cyprus, i.e. in the upper part of the discontinuity layer where a second peak of particle concentrations was measured (Fig. 2). At $200 \mathrm{~m}$, the concentrations of Chl $a$ were beyond the limit of detection.

Pico/nanophytoplankton (cells $<20 \mu \mathrm{m}$ ) contributed almost exclusively to the $\mathrm{Chl} a$ and the total cell numbers (Fig. 3), which were positively correlated $(P<0.001$,

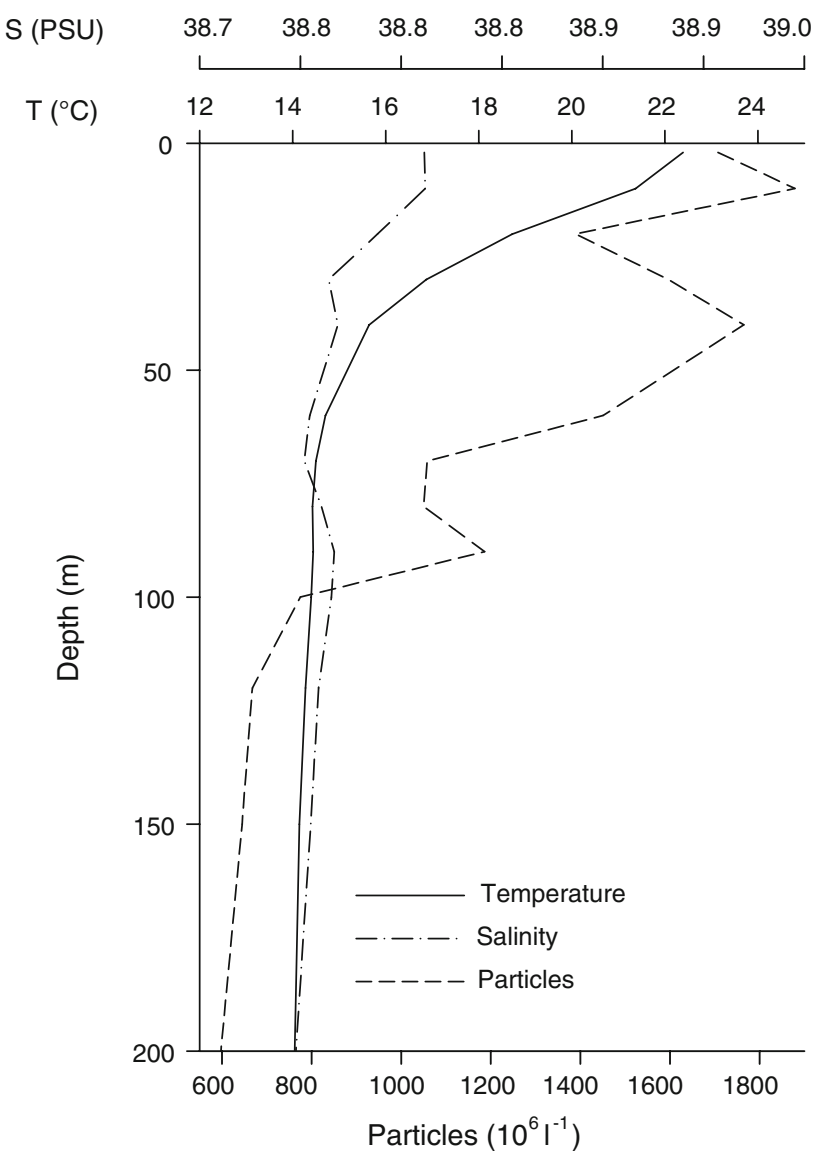

Fig. 2 Distribution of temperature, salinity and particle numbers (2.6-30 $\mu \mathrm{m}$ ) in the upper $200 \mathrm{~m}$ in the area of the Ierapetra-Deep (site A) in June 1993 (Lenz, unpublished data)

Detmer 1995). The size fraction of autotrophic picoplankton $(<2 \mu \mathrm{m})$ increased when moving from west to east, averaging $43 \%$ off Crete, $62 \%$ off SW Cyprus and $76 \%$ off NE Cyprus. In the DCM off Crete (Fig. 3), the site which will be referred to almost exclusively in the present study, the numbers of cells $<20 \mu \mathrm{m}$ varied between $3 \times 10^{7}$ and $8 \times 10^{7}$ cells $/ 1$. The maxima of eukaryotic autotrophs (up to $1.5 \times 10^{7}$ cells/l) and coccoid cyanobacteria (Synechococcus) concurred at 60-80 m. Here, the last group was predominant with up to $4 \times 10^{7}$ cells $/$ l. Prochlorophytes (up to $2.2 \times 10^{7}$ cells/l) climaxed somewhat deeper between 60 and $100 \mathrm{~m}$ (Detmer 1995).

\section{Results}

Occurrence and standing stocks

The standing stock of thaliaceans and species diversity climaxed at site A (Tables 1,2), but the individual counts at all sites were small, accounting for only $0.15 \%$ of the mesozooplankton off SE Crete (site A), $0.06 \%$ off SW 


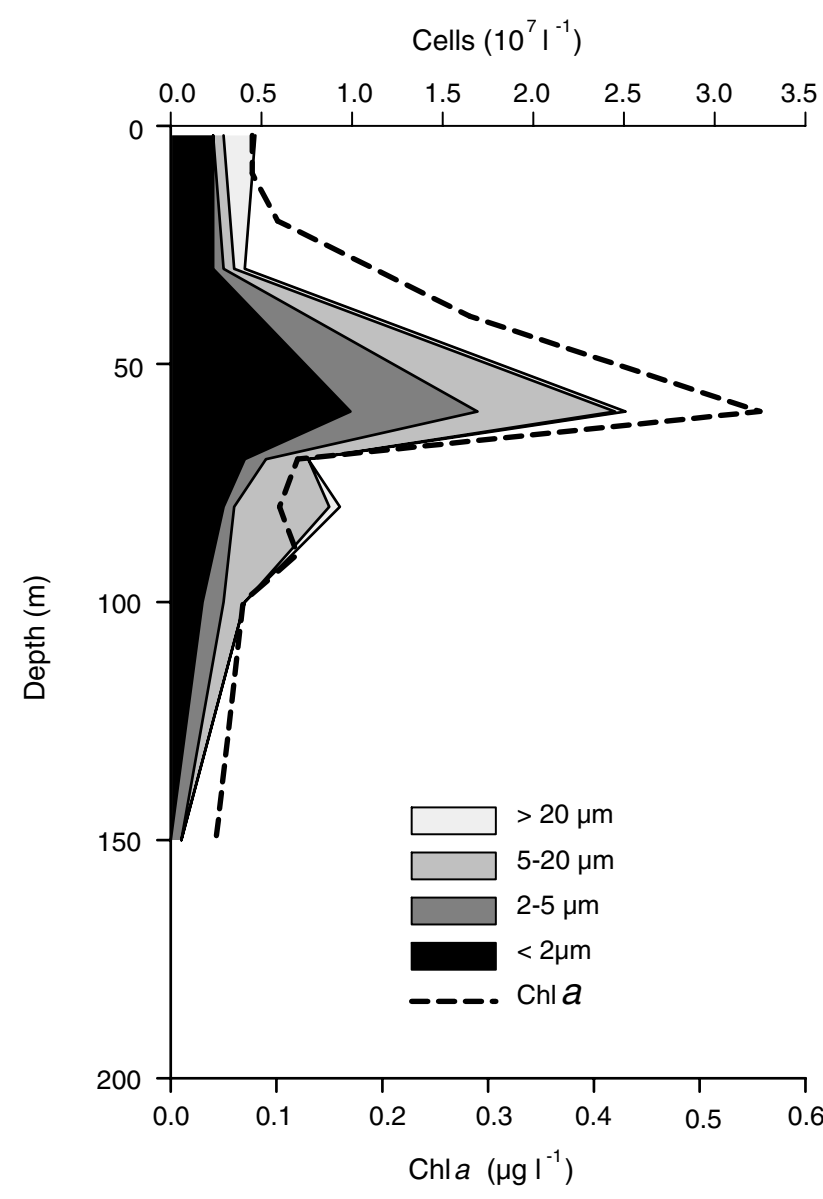

Fig. 3 Distribution of size fractionated chlorophyll $a\left(\mu \mathrm{gl}^{-1}\right)$ and cell numbers (autotrophic pico and nanoplanton, cells $10^{7} 1^{-1}$ ) in the upper $200 \mathrm{~m}$ in the area of the Ierapetra-Deep (site A) in June 1993 (Lenz unpublished cell numbers; modified from Detmer 1995)

Cyprus (B) and $0.2 \%$ off NE Cyprus (C). The standing stock at site A was significantly larger (Mann-Whitney $U$ test $P<0.01 ; n: 7 ; 8)$ than those at the Cyprian sites B and $\mathrm{C}$ which were not different from each other $(P>0.05 ; n: 4$; 4). Among the three thaliacean orders doliolids were predominant, comprising $96 \%$ of the thaliacean standing stock at site A. Salps ranked second (11\%). A total of six doliolid species, one pyrosomatid and four salp species were collected at site A, plus Cyclosalpa polae found in the MOC10. Off Cyprus, five doliolid species made up the total thaliacean standing stock, except for a negligible number of $P$. atlanticum at site B (Table 2).

The averaged species counts were highest at site A, except for $P$. atlanticum (Tables 1,2), but the speciesspecific variability at the sites was consistently high. Only two species exhibited an overall data set allowing for a Mann-Whitney $U$-test. It revealed a significantly increased standing stock for D. muelleri at site A versus site C $(P=0.05 ; n: 7 ; 4)$, while the latter stock was larger than that at site $\mathrm{B}(P<0.05 ; n: 4 ; 4)$. The standing stocks of
D. gegenbauri were not significantly different $(P>0.05)$ among sites. The outstanding large standing stock of $D o$ liolum nationalis at site $\mathrm{A}$ is self-explanatory.

D. nationalis, all of them phorozooids, comprised $67 \%$ of the doliolids at site $\mathrm{A}$, and contributed with $62 \%$ substantially to the local thaliacean fauna. In contrast to this species, the other doliolids were represented by different stages, with nurses prevailing off Cyprus (Tables 1, 2). Among the Salpida, Salpidae were predominant, and aggregate forms (proles gregata, PG) outnumbered solitary forms (proles solitaria, PS). Only three specimens of Cyclosalpidae were encountered (site A): a damaged and doubtful PG of Helicosalpa virgula, and two specimens of C. polae $(\mathrm{PG})$ in a MOC10 sample. The rare P. atlanticum (Pyrosomatida) were represented by all stages of development, from the tetrazooid colonies to mature colonies.

\section{Vertical distribution and migration of species}

Among the rare species, D. krohni (if clearly identified) and Doliolum denticulatum were exclusively found at 25$75 \mathrm{~m}$ and $H$. virgula at $75-125 \mathrm{~m}$. C. polae was found in a MOC10 sample at 50-100 m. P. atlanticum was collected at the sites between 575 and $750 \mathrm{~m}$ by day and within the upper $135 \mathrm{~m}$ by night. Apart from D. nationalis which was represented solely by phorozooids, stages other than nurses at site A were most abundant in the 25-75 m-layer (206.0 \pm 508.6 ind. $1,000 \mathrm{~m}^{-3}$ ) as compared to the adjacent $0-25$ and $75-100$ m-layers $\quad(8.7 \pm 22.5$ ind. $1,000 \mathrm{~m}^{-3}$ and $17.3 \pm 32.9$ Ind. $1,000 \mathrm{~m}^{-3}$, respectively), but the differences were not significant (Mann-Whitney $U$ test, $P>0.05 ; n: 8 ; 8)$.

The remaining seven species were abundant enough at site A to allow for a day/night comparison of their respective standing stocks, with no significant differences in abundance between the two time periods (Mann-Whitney $U$-test, $P>0.05$; Table 3 ), and to allow for illustrating their vertical distribution (Fig. 4). In order to determine the vertical partitioning of a species at day and at night in the water column, the average weighted mean depths (WMD) for the day and night were calculated for each species (Table 4). When compared by a Bonferroni-adjusted $t$-test $(P>0.05)$ no significant differences were found, except for $S$. fusiformis $(P \leq 0.03)$. Doliolinetta intermedia was excluded from the test since only one positive sample was available for the night-time.

By exclusion of the day-time data for the diel migrator S. fusiformis, significant differences were found between the WMDs of the epipelagic species (Kruskal Wallis test, $P<0.05$ ), allowing for a consecutive Tukey-Kramer test at $P<0.1$ (Sachs 1999). This revealed a significant difference between the centres of abundance occupied by $T$. 
Table 1 Standing stocks (means and standard deviation) of thaliaceans (ind. $/ \mathrm{m}^{2}$ ) at site A, SE off Crete

\begin{tabular}{|c|c|c|c|c|c|c|c|c|c|}
\hline Taxon & Standing stock & $\%$ & $\mathrm{~N}$ & PS & PG & $\mathrm{PZ}$ & $\mathrm{GZ}$ & $\mathrm{Ooz}$ & Larvae \\
\hline Dolioletta gegenbauri & $8.2 \pm 13.9$ & 8.5 & 2.7 & & & 0.1 & $<0.1$ & 2.6 & 2.9 \\
\hline Doliolina krohni ${ }^{\mathrm{a}}$ & 0.9 & 0.9 & $<0.1$ & & & & 0.8 & & \\
\hline Doliolina muelleri & $12.1 \pm 7.2$ & 12.6 & 11.2 & & & & 0.1 & 0.8 & \\
\hline Doliolina muelleri/D. krohni ${ }^{\mathrm{a}}$ & 7.2 & 7.5 & 1.6 & & & & 1.4 & 3.7 & 0.6 \\
\hline Doliolinetta intermedia & $0.6 \pm 1.0$ & 0.6 & 0.5 & & & 0.2 & & & \\
\hline Doliolum denticulatum $^{\mathrm{a}}$ & 0.2 & 0.2 & & & & & $<0.1$ & 0.2 & \\
\hline Doliolum nationalis & $67.2 \pm 69.0$ & 69.7 & & & & 67.2 & & & \\
\hline Doliolida, total & 96.4 & 89.5 & 16.0 & & & 67.5 & 2.3 & 7.3 & 3.5 \\
\hline Helicosalpa virgula ${ }^{\mathrm{a}}$ & $<0.1$ & & & & $<0.1$ & & & & \\
\hline Salpa fusiformis & $0.6 \pm 0.6$ & 5.3 & & 0.2 & 0.5 & & & & \\
\hline Thalia democratica & $3.0 \pm 5.0$ & 26.5 & & 1.0 & 2.1 & & & & \\
\hline Thalia orientalis & $6.2 \pm 6.1$ & 54.9 & & 1.9 & 4.3 & & & & \\
\hline Unidentified & 1.5 & 13.2 & & & & & & & \\
\hline Salpida, total & 11.3 & 10.5 & & 3.1 & 6.9 & & & & \\
\hline Pyrosoma atlanticum ${ }^{\mathrm{a}}$ & $<0.1$ & & & & & & & & \\
\hline Pyrosomata, total & $<0.1$ & & & & & & & & \\
\hline Total standing stock & $107.7 \pm 102.9$ & 100.0 & 16.0 & 3.1 & 6.9 & 67.4 & 2.4 & 7.3 & 3.4 \\
\hline Zooplankton standing stock & $73,931.0$ & & & & & & & & \\
\hline
\end{tabular}

Percentages refer to the nearest higher-ranking unit. Total zooplankton standing stock from Weikert et al. 2001

$N$ nurses, $P S$ proles solitaria, $P G$ proles gregata, $P Z$ phorozooids, $G Z$ gonozooids, $\mathrm{Ooz}$ oozooids

${ }^{a}$ Erratic or singular findings

orientalis and $D$. nationalis $(P<0.05)$ as well as between those of $T$. orientalis on the one hand and $T$. democratica and D. muelleri on the other hand $(P<0.1$; Table 5). Obviously, $T$. orientalis showed a lesser affinity to the uppermost $25 \mathrm{~m}$ over the whole day as compared to the other three species.

The findings at either site off Cyprus appear to fit the species' vertical patterns at site A except for $D$. muelleri (nurses), the most abundant species at site C (90\% of thaliaceans). Two positive night-time hauls out of three hauls performed in the area of an intermittent anticyclonic gyre (Yilmaz et al. 1994) yielded considerable counts between 225 and $875 \mathrm{~m}$ comprising some $70 \%$ of the standing stock. The respective abundances varied between 0.5 ind. $1,000 \mathrm{~m}^{-3}$ at $725-875 \mathrm{~m}$ and 74.5 ind. $1,000 \mathrm{~m}^{-3}$ at $375-425 \mathrm{~m}$.

\section{Discussion}

Composition and standing stock of thaliaceans

Our data on the populations of thaliacean species in the Levantine Sea are a snapshot. Only a limited set of species from the livestock reviewed in Godeaux (1999) was recorded. $H$. virgula, on the other hand, so far known from the central Mediterranean (Godeaux 1999), may be the first record from the eastern basin, but the sole and severely damaged specimen could not be identified with certainty. $P$. atlanticum, one of the main blooming thaliaceans in the western Mediterranean (Franqueville 1971; Andersen and Sardou 1994), was recorded with all developmental stages for the first time from northern Levantine waters and appears to have established an indigenous population. Earlier findings were from the southern part of the basin and the central Mediterranean (Galil and Goren 1994; Godeaux 1987, 1999). Colonies not identified to species level have been reported from off Rhodes and the Levantine Basin (Mazzocchi et al. 1996). No Lessepsian species was found, although a number of thaliacean species in the Red Sea are considered potential migrants to the basin (Godeaux 1999).

In January 1998, the collection of zooplankton was repeated at site A. Due to unspecified losses when counted specimens were transferred into vials for taxonomic identification, quantitative statements are impossible. $P$. atlanticum was again present with a complete biological cycle. Among the Doliolidae, D. gegenbauri $(\mathrm{N})$ and $D$. intermedia $(\mathrm{N})$ were the commonest, accompanied by $D$. muelleri (Ooz, $\mathrm{N})$, D. nationalis (PZ), and D. denticulatum (Ooz, PZ, GZ). Salps were represented by $S$. fusiformis, $T$. orientalis and the dominant $T$. democratica. In the sparsely investigated northern Aegean Sea, a few specimens of D. muelleri (Ooz, N), D. denticulatum 
Table 2 Standing stocks (means and standard deviation) of thaliaceans (ind. $/ \mathrm{m}^{2}$ ) at sites B, SW off Cyprus (I) and C, NE off Cyprus (II)

\begin{tabular}{|c|c|c|c|c|c|c|}
\hline Taxon & $\begin{array}{l}\text { Standing } \\
\text { Stock }\end{array}$ & $\%$ & $\mathrm{~N}$ & $\mathrm{PZ}$ & $\mathrm{GZ}$ & Ooz \\
\hline \multicolumn{7}{|l|}{ I SW off Cyprus } \\
\hline Dolioletta gegenbauri & $1.2 \pm 1.2$ & 66.7 & 1.2 & & & \\
\hline Doliolina krohni ${ }^{\mathrm{a}}$ & 0.1 & 5.6 & & & 0.1 & \\
\hline Doliolina muelleri & $0.5 \pm 0.4$ & 27.8 & 0.4 & & & 0.1 \\
\hline Doliolum nationalis ${ }^{\mathrm{a}}$ & $<0.1$ & & & $<0.1$ & & \\
\hline Unidentified & $<0.1$ & & & & & \\
\hline Doliolida, total & $1.8 \pm 1.7$ & 94.7 & 1.6 & $<0.1$ & 0.1 & 0.1 \\
\hline Pyrosoma atlanticum ${ }^{\mathrm{a}}$ & 0.1 & 100 & & & & \\
\hline Pyrosomata, total & 0.1 & 5.2 & & & & \\
\hline Total standing stock & $1.9 \pm 1.7$ & 99.9 & 1.6 & $<0.1$ & 0.1 & 0.1 \\
\hline $\begin{array}{l}\text { Zooplankton standing } \\
\text { stock }\end{array}$ & $3,239.0$ & & & & & \\
\hline \multicolumn{7}{|l|}{ II NE off Cyprus } \\
\hline Dolioletta gegenbauri $^{\mathrm{a}}$ & 0.2 & 4.0 & 0.2 & & & \\
\hline Doliolina muelleri & $4.5 \pm 4.3$ & 90.0 & 4.0 & & & 0.4 \\
\hline Doliolinetta intermedia ${ }^{\mathrm{a}}$ & 0.2 & 4.0 & 0.2 & & & \\
\hline Doliolum nationalis ${ }^{\mathrm{a}}$ & 0.1 & 2.0 & & 0.1 & & \\
\hline Unidentified & $<0.1$ & & & & & \\
\hline Doliolida, total & $5.0 \pm 4.0$ & 100.0 & 4.4 & 0.1 & & 0.4 \\
\hline Total standing stock & $5.0 \pm 4.0$ & 100.0 & 4.4 & 0.1 & & 0.4 \\
\hline $\begin{array}{l}\text { Zooplankton standing } \\
\text { stock }\end{array}$ & $2,236.0$ & & & & & \\
\hline
\end{tabular}

Percentages refer to the nearest higher-ranking unit. Species of the orders are being ranked according to Table 1. Total zooplankton standing stock from Elwers 1995

${ }^{\text {a }}$ Erratic or singular findings

Table 3 Mean number and standard deviation of individuals $\mathrm{m}^{-2}$ for the most abundant thaliacean species in the upper $400 \mathrm{~m}$ of the water column at site A, SE off Crete

\begin{tabular}{lcc}
\hline Species & Day $(n=4)$ & Night $(n=3)$ \\
\hline Dolioletta gegenbauri & $12.4 \pm 18.0$ & $2.1 \pm 1.7$ \\
Doliolina muelleri & $10.4 \pm 4.5$ & $14.1 \pm 10.7$ \\
Doliolinetta intermedia & $0.6 \pm 1.0$ & $0.7 \pm 1.2$ \\
Doliolum nationalis $^{\text {Salpa fusiformis }}{ }^{\mathrm{a}}$ & $88.1 \pm 86.9$ & $38.7 \pm 30.3$ \\
Thalia democratica & $0.7 \pm 0.7$ & $0.5 \pm 0.1$ \\
Thalia orientalis & $5.1 \pm 6.1$ & $0.3 \pm 0.3$ \\
\hline
\end{tabular}

Day-night differences ( $U$-test) not significant at the 0.05 level $n$ number of samples

a $S$. fusiformis: $n$ day $=5$ (see "Material and methods")

$(\mathrm{Ooz}, \mathrm{N}), D$. gegenbauri $(\mathrm{N})$ and $T$. orientalis $(\mathrm{PS})$ were caught in the Sporades Basin, around $39^{\circ} 17^{\prime} \mathrm{N} / 23^{\circ} 33^{\prime} \mathrm{E} . T$. democratica, reported to be dominant in the eutrophic north Aegean Sea (Kiortsis 1974), was not found.
Quantitative information on thaliaceans from sub-basins adjacent to the Levantine Sea is rare. Near to the coast of northern Rhodes, the share of thaliaceans in total zooplankton collected during four months with $0.200 \mathrm{~mm}$ nets in the upper $50-350 \mathrm{~m}$ varied between virtual absence $(0.03 \%)$ and $3.27 \%$, with maxima in February and May and minima in August and November (Siokou-Frangou and Papathanassiou 1989). Estimated averages of salps calculated from that study are about 24 ind $1,000 \mathrm{~m}^{-3}$ in summer, and 1,100 ind. $1,000 \mathrm{~m}^{-3}$ in winter. Doliolids were always present. Except in autumn (60 ind. 1,000 $\mathrm{m}^{-3}$ ) when no salps were collected, the averaged counts varied between 200 and 300 ind. $1,000 \mathrm{~m}^{-3}$. In the open Ionian Sea, samples (mesh size no. 46, which corresponds to $0.170 \mathrm{~mm}$ according to Scotto di Carlo and Ianora 1983) averaged up to 24,600 salps $1,000 \mathrm{~m}^{-3}$ in the $10-25 \mathrm{~m}$ layer and 9,500 doliolids $1,000 \mathrm{~m}^{-3}$ in the $50-100 \mathrm{~m}$ layer of maximum occurrence in summer, possibly indicating the existence of blooms (Greze 1963). D. denticulatum and, like near to Rhodes, $T$. democratica were conspicuous. In either study the finer mesh sizes used may have resulted in higher numbers as compared to our study, especially concerning the small-sized oozooids of doliolids.

In the northwestern Mediterranean, thaliaceans have been observed weekly over some 25 years at a site in the Bay of Villefranche-sur-mer, using a $0.680 \mathrm{~mm}$ mesh size. The surface temperature seems to be the only environmental factor which significantly influences the distribution of salps. The most common S. fusiformis and T. democratica were most abundant in spring/early summer, the first species showing a strong decrease in August/September (Licandro et al. 2006). The doliolids begin to be numerous from May-June, with peaks of abundance in summer and autumn when the numbers of salps decrease (Braconnot et al. 1990; Braconnot and Dallot 1995) and the environment is most oligotrophic (Menard et al. 1997). In samples based on a $0.700 \mathrm{~mm}$ mesh size, S. fusiformis may reach 20,000 ind./1,000 $\mathrm{m}^{3}$ in the upper $75 \mathrm{~m}$ (Braconnot et al. 1990), and numbers of the most abundant $D$. nationalis may be even twice as high (Braconnot and Dallot 1995). Counts of $P$. atlanticum based on $0.500 \mathrm{~mm}$ meshes varied between rare findings and up to 187 colonies $1,000 \mathrm{~m}^{-3}$ according to season (Andersen et al. 1994). Possible seasonal variations included and corroborating previous faunistic studies (Godeaux 1999, and references therein), the thaliacean fauna is richer in species and specimens as compared to the eastern Mediterranean, where phytoplankton and bacterial production is up to three times less than in the western Mediterranean Sea (Turley et al. 2000). Notwithstanding, the seasonal fluctuations of salps and doliolids in the SE Aegean Sea (Siokou-Frangou and Papathanassiou 1989) seem to fit the respective pattern in the western Mediterranean Sea. 
Fig. 4 Vertical distribution of abundant thaliacean species in June 1993 above the Ierapetra Deep (site A). The bars represent the mean and the sticks the standard errors. Shaded bars day-time, black bars night-time
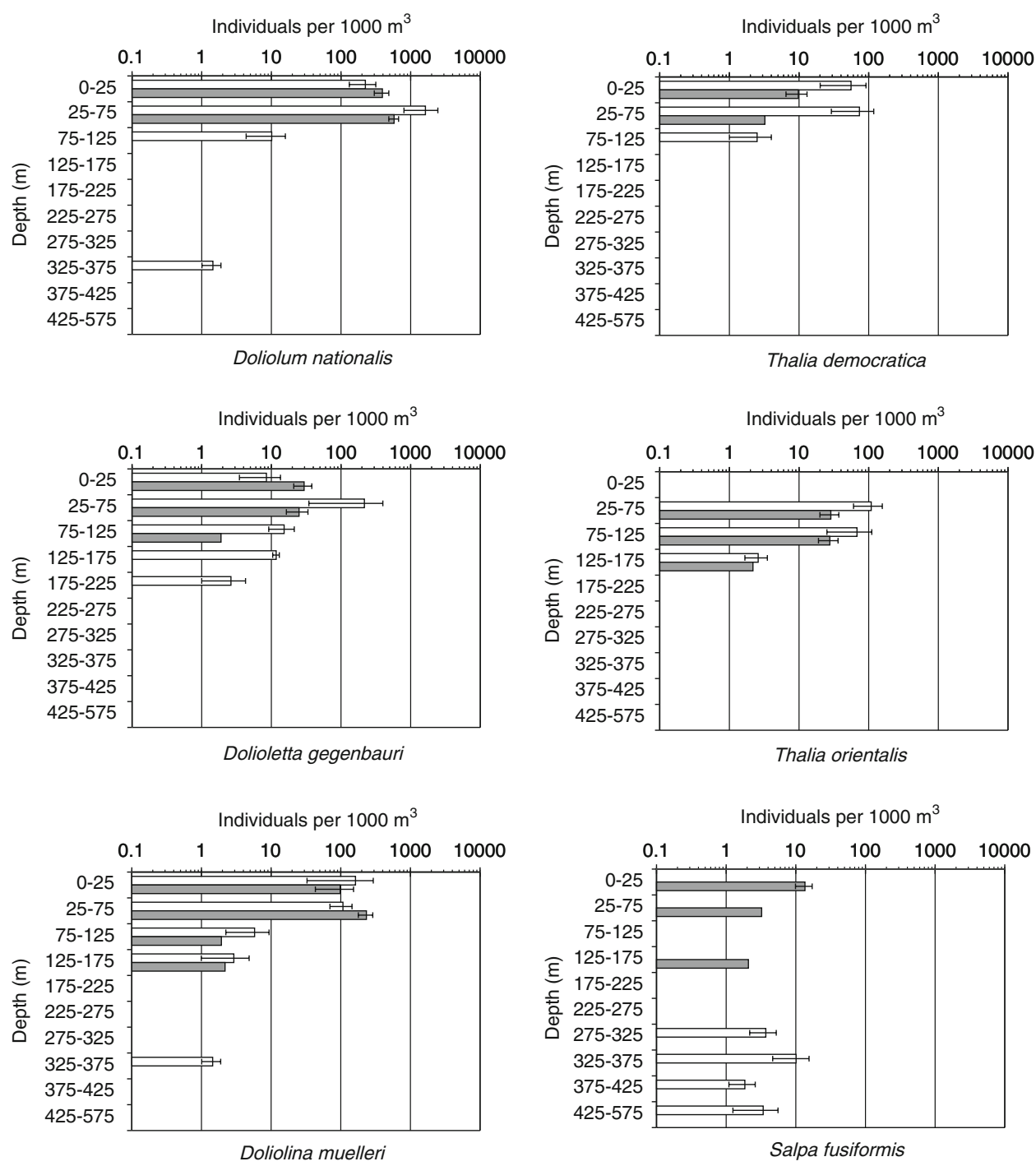

Table 4 Average weighted mean depths (WMD) \pm standard deviations at day-time and night-time for the most abundant thaliacean species at site A, SE off Crete

\begin{tabular}{lcc}
\hline Species & WMD (day) & WMD (night) \\
\hline Dolioletta gegenbauri & $75.9 \pm 19.4$ & $45.1 \pm 13.1$ \\
Doliolina muelleri & $47.8 \pm 19.5$ & $45.5 \pm 3.1$ \\
Doliolinetta intermedia $^{\mathrm{a}}$ & $64.9 \pm 21.0$ & 33.1 \\
Doliolum nationalis $_{\text {Salpa fusiformis }}$ & $47.2 \pm 3.8$ & $40.7 \pm 3.1$ \\
Thalia democratica & $362.7 \pm 43.7$ & $39.0 \pm 23.2$ \\
Thalia orientalis & $44.4 \pm 6.5$ & $37.5 \pm 21.7$ \\
\hline
\end{tabular}

Day-night differences ( $t$-test) not significant at the 0.05 level except for $S$. fusiformis

${ }^{\text {a }}$ Not tested, see text

Our data from June 1993 indicate also a decline in species and individual richness from SE of Crete (site A) to SW and NE of Cyprus (sites B and C, respectively). The conspicuous predominance of the blastogenetic $D$. nationalis over salps at site A apparently features the phenology of the summer season (Table 1). Even though this neritic species was not entrained by the local anticyclonic eddy in high numbers, expatriates into the oceanic Ierapetra-Deep area may have benefitted from a high phytoplankton availability by rapid budding which is a competitive advantage over oceanic species. Yet, even the high counts of D. nationalis of 4,095 ind. $1,000 \mathrm{~m}^{-3}$ in a rich $25-75 \mathrm{~m}$-sample are by a factor of ten less as compared to blooms in the western Mediterranean.

Aside from a supra-regional comparison, the counts of thaliaceans at the studied sites were low in absolute numbers and relative to the local zooplankton. This is typical of oceanic sites for most of the time when there are no blooming events. In June 1993, when the EMT was at its climax (Roether et al. 2007), the population of thaliaceans was insignificantly increased (Table 6) as compared to studies before (1987) and after $(1998,1999,2001)$ the 
Table 5 Significance of the Tukey-Kramer test applied for the most abundant species of thaliaceans at site A, SE off Crete

\begin{tabular}{|c|c|c|c|c|c|c|}
\hline & $\begin{array}{l}\text { Doliolina } \\
\text { muelleri } \\
n=7\end{array}$ & $\begin{array}{l}\text { Dolioletta } \\
\text { gegenbauri } \\
n=7\end{array}$ & $\begin{array}{l}\text { Doliolum } \\
\text { nationalis } \\
n=7\end{array}$ & $\begin{array}{l}\text { Salpa } \\
\text { fusiformis } \\
n=3\end{array}$ & $\begin{array}{l}\text { Thalia } \\
\text { democratica } \\
n=7\end{array}$ & $\begin{array}{l}\text { Thalia } \\
\text { orientalis } \\
n=7\end{array}$ \\
\hline Doliolina muelleri & - & $12.43<15.37$ & $1.57<15.37$ & $1.76<19.85$ & $1.0<16.93$ & $16.43>15.37$ \\
\hline Dolioletta gegenbauri & $12.43<16.93$ & - & $14.00<15.37$ & $14.19<19.85$ & $11.43<16.93$ & $4.00<16.93$ \\
\hline Doliolum nationalis & $1.57<16.93$ & $14.00<16.93$ & - & $0.52<19.85$ & $2.71<16.93$ & $19.29>15.37$ \\
\hline Salpa fusiformis & $1.76<21.85$ & $14.19<21.85$ & $0.52<21.85$ & - & $2.71<16.93$ & $19.81<19.85$ \\
\hline Thalia democratica & $1.0<16.93$ & $11.43<16.93$ & $2.71<16.93$ & $3.24<21.85$ & - & $16.14>15.37$ \\
\hline Thalia orientalis & $16.43<16.93$ & $4.00<16.93$ & $19.29>16.93$ & $19.81<21.85$ & $16.14<16.93$ & - \\
\hline
\end{tabular}

Bold numbers indicate difference between the centres of vertical distribution: upper part at the 0.1 level, lower part at the 0.05 level. Diel migrator $S$. fusiformis only night data

$n$ number of samples

Table 6 The standing crop (mean \pm SD) and relative abundance (\% of zooplankton) of thaliaceans in the upper 1,050 $\mathrm{m}$ of the water column at site A, SE off Crete, in different years.

\begin{tabular}{|c|c|c|c|c|}
\hline Year, month & Ind. $/ \mathrm{m}^{2}$ & $\%$ & $n$ & Data referring to \\
\hline 1987, January & $44.9 \pm 43.0$ & 0.3 & 4 & Weikert and Trinkaus 1990 \\
\hline 1993, June & $107.7 \pm 102.9$ & 0.2 & 7 & Weikert et al. 2001 \\
\hline 1998, January & $48.1 \pm 29.1$ & 0.4 & 3 & Weikert, unpublished \\
\hline 1999, April & $53.1 \pm 16.2$ & 0.3 & 4 & Koppelmann and Weikert 2007 \\
\hline 2001, October/November ${ }^{\mathrm{a}}$ & $66.4 \pm 40.2$ & 0.4 & 2 & Koppelmann and Weikert 2007 \\
\hline
\end{tabular}

Number of profiles $(n)$. Sampling devices: D-MOC, 1987 single MOC; all nets of 0.333 mesh size. Standing crop differences (Kruskal and Wallis-Test; ${ }^{a}$ not included) are not significant at the 0.05 level $\left(3.025<5.991=\chi_{3 ; 0.05}^{2}\right)$

climatic change in hydrography, although a phytoplankton bloom prior to our study was evidenced. Chloroplastic pigment equivalents as well as bacterial biomass and activity at the abyssal sea floor were significantly elevated as compared to contiguous sites and previous years (Boetius et al. 1996). The zooplankton standing stock was exceptionally large, almost exclusively supported by resting stages of the herbivorous calanoid copepods Calanus helgolandicus and Eucalanus monachus at mainly mesopelagic and bathypelagic depths as deep as 4,000 m (Weikert 1995, Weikert et al. 2001). Species of the respective genera are well-known to take full advantage of phytoplankton blooms and to diapause at depth during oligotrophic conditions.

Faecal pellets of large copepods as a potential transport vehicle of phytoplankton to the sea floor can sink at similar rates as doliolid faeces (Small et al. 1979). The processes which favour the likely competitive outbreaks of copepods and thaliaceans are poorly understood (Licandro et al. 2006), but particle size of food might be an important agent. Calanoid copepods, in general, feed most effectively on particles $>5 \mu \mathrm{m}$ in size. Thus, the overwhelming abundance of the dormant coarse filterers $C$. helgolandicus and E. monachus argues against a preceding bloom of mainly small-sized autotrophs and a food web dominated by thaliaceans.

\section{Vertical distribution and migration}

Vertically habitat-partitioning was evident among species of salps. In the epipelagic zone, the centre of distribution of $T$. orientalis was significantly different from that of $T$. democratica (Table 5, Fig. 4). The first species appeared to be closer associated with the DCM and the broad, deep maximum of particles (Figs. 2, 3), while the latter species abounded also in the phytoplankton-poor but particle-rich 0-25 m surface layer (Fig. 2). Salps can be regarded as ecological equivalents due to an apparent overlap in diet among species (Madin and Deibel 1998). The restricted occurrence of $T$. orientalis may reduce food competition on $T$. democratica, whereas competition pressure by $S$. fusiformis in the surface layers is restricted to the night-time. In the mesopelagic zone, the population of the diel migrator was observed at depths $\leq 575 \mathrm{~m}$ at day-time (Fig. 4, Table 4), at shallower depths than the rare findings of $P$. atlanticum. In the southern Levantine Sea, Galil and Goren (1994) caught three colonies of $P$. atlanticum below $1,400 \mathrm{~m}$, i.e. $500 \mathrm{~m}$ deeper than our utmost record. 
Among the doliolid species (Fig. 4) and their stages, a segregation in space could not be proved statistically, although $D$. intermedia was not collected in the top $25 \mathrm{~m}$ at day-time, and feeding stages (phorozooids, oozooids, gonozooids) of the D. muelleri-krohni group, D. gegenbauri, D. intermedia and $D$. denticulatum were most abundant at depths below $25 \mathrm{~m}$ contrasting to the extended vertical distribution of the neritic, blastogenetic $D$. nationalis, which was represented solely by phorozooids (Table 1). Its occurrence throughout the euphotic zone at varying cell concentrations (Fig. 4) might be hypothesized from feeding experiments: unlike neritic species ( $T$. democratica), larger oceanic salps (S. fusiformis) which live in diluted particle concentrations cannot adjust filtration to changing particle concentrations (Deibel 1982; Madin and Deibel 1998). Nurses, which do not feed as deprived of any digestive tract, showed a vertically extended distribution similar to $D$. nationalis.

It is impossible to correlate statistically the species' abundances with the phytoplankton and particle concentrations. Irrespectively of the fact that we do not have access to the original data, the above concentrations were measured with a time lag ranging from some hours to four days relative to the MOC tows and at differing geographical positions, since the sampling strategy for zooplankton was designed for deep-sea studies (Weikert et al. 2001). Also, the coarse subsampling of the upper $200 \mathrm{~m}$ by $25 \mathrm{~m}$ and $50 \mathrm{~m}$ layers inevitably blurred vertical biological structures. Dives, for example, showed a doliolid abundance decreasing by two orders of magnitude over a vertical distance of only $2 \mathrm{~m}$ (Paffenhöfer et al. 1991). However, time-series suggest that the depth where reproduction takes place and thaliacean stages are distributed seasonally, may be related to environmental variables such as temperature, salinity and food (Licandro et al. 2006), depending on species (Paffenhöfer et al. 1995; Tew and Lo 2005). But the coupling may be subject to environmental disturbance as examplified by the conspicuous mesopelagic findings of thaliaceans at site C (see above). Paffenhöfer and Gibson (1999) reported on asexually reproducing $D$. gegenbauri in the top 1-13 m before, and their vertical dispersion after, a storm-induced turbulence.

Differential grazing in thaliaceans would allow spatial coexistence of salps and doliolids, although some vertical separation is indicated for $T$. orientalis versus the doliolids D. nationalis and D. muelleri (Table 5). Madin and Deibel (1998) and Bone et al. (2003) related the most recent results on thaliacean feeding experiments to observations in the field. They suggested that small doliolid stages should at least be capable of filtering small nanoplankton and even picoplankton particles efficiently, and doliolids "are thus apparently significantly different from salps" (Madin and Deibel 1998, page 85). Such a difference would not only explain the dominance of doliolids over salps during our study, when the portion of nanoplankton and picoplankton was large, but also the diverging horizontal distribution pattern of both groups. The virtual absence of salps from the sites off Cyprus was associated with low cell numbers und a relative decrease of cells sizes $>2 \mu \mathrm{m}$, from $57 \%$ off Crete to about $38 \%$ off SE Cyprus and $24 \%$ off NE Cyprus (Detmer 1995), which are most efficiently grazed by salps (Madin and Deibel 1998; Bone et al. 2003; Vargas and Madin 2004). Under the increased oligotrophic conditions doliolids were almost exclusively represented by non-feeding stages (nurses).

Acknowledgments Thanks are due to Mrs. R. Gollembiewski who assisted in evaluating the plankton samples and to Rolf Koppelmann for technical support for the Figs. 1, 2, 3. Sampling with R.V. "Meteor" and quantitative sorting of the zooplankton samples into major groups was supported by grants from the Deutsche Forschungsgemeinschaft (WE 695/15) to H.W. which is gratefully acknowledged.

\section{References}

Aldredge A, Madin LR (1982) Pelagic tunicates: unique herbivores in the plankton. Bioscience 32:655-663

Andersen V (1998) Salp and pyrosomid blooms and their importance in biogeochemical cycles. In: Bone Q (ed) The Biology of pelagic Tunicates. Oxford University Press, Oxford, pp 125-137

Andersen V, Sardou J (1994) Pyrosoma atlanticum (Tunicata, Thaliacea): diel migration and vertical distribution as a function of colony size. J Plankton Res 16:337-349

Andersen V, Sardou J, Nival P (1994) The diel migrations and vertical distributions of zooplankton and micronekton in the Northwestern Mediterranean Sea. 2. Siphonophores, hydromedusae and pyrosomids. J Plankton Res 14:1155-1169

Berner LD (1967) Distributional atlas of Thaliacea in the California Current region. CalCOFI Atlas 8:1-322

Boetius A, Scheibe S, Tselepides A, Thiel H (1996) Microbial biomass and activities in deep-sea sediments of the Eastern Mediterranean: trenches are benthic hotspots. Deep-Sea Res 43:1439-1460

Bone Q, Carré C, Chan P (2003) Tunicate feeding filters. J Mar Biol Ass UK 83:907-919

Braconnot J-C, Dallot M (1995) Distribution des Tuniciers pélagiques Doliolides à Villefranche: 10 années d'observations. Rapp Comm Int Mer Médit 34:204

Braconnot J-C, Etienne M, Moitie M (1990) Distribution du Tunicier Salpa fusiformis Cuvier à Villefranche: 18 années d'observations. Rapp Comm Int Mer Médit 32:225

Caron DA, Madin LP, Cole JJ (1989) Composition and degradation of salp fecal pellets: implications for vertical flux in oceanic environments. J Plankton Res 47:829-850

CIESM (2001) Gelatinous zooplankton outbreaks: theory and practice. Monaco: CIESM Workshop Monographs No. 14, p 112

Deevey CW (1971) The annual cycle in quantity and composition of the zooplankton of the Sargasso Sea of Bermuda. Limnol Oceanogr 16:219-240

Deibel D (1982) Laboratory-measured grazing and ingestion rates of the salp Thalia democratica Forskal, and the doliolid, Dolioletta gegenbauri Uljanin (Tunicata, Thaliacea). J Plankton Res 4:189_ 201 
Deibel D (1985) Blooms of the pelagic tunicate, Dolioletta gegenbauri: are they associated with Gulf Stream frontal eddies? J Mar Res 43:211-236

Deibel D (1998) The abundance, distribution, and ecological impact of doliolids. In: Bone Q (ed) The Biology of pelagic Tunicates. Oxford University Press, Oxford, pp 171-189

Detmer A (1995) Verbreitung, Abundanz und Bedeutung von autotrophem Pico- und Nanoplankton in polaren, temperierten und subtropischen Regionen. Ber IfM Kiel, 263, Kiel, Germany

Dubischar CD, Bathmann UV (1997) Grazing impact of copepods and salps on phytoplankton in the Atlantic sector of the Southern Ocean. Deep-Sea Res II 44:415-433

Dugdale RC, Wilkerson FP (1988) Nutrient sources and primary production in the Eastern Mediterranean. In: Minas HJ, Nival P (eds) Océanographie pélagique méditerranéenne. Oceanol. Acta 9:179-184

Ediger D, Tugrul S, Yilma A (2005) Vertical profiles of particulate organic matter and its relationship with chlorophyll- $a$ in the upper layer of the NE Mediterranean Sea. J Mar Syst 55:311326

Elwers K (1995) Untersuchung zur Zusammensetzung und Verteilung des Mesozooplanktons auf zwei Lokationen der östlichen Levantischen See im Sommer 1993, unter besonderer Berücksichtigung der Copepoda Calanoida (Crustacea). Diploma Thesis, University Hamburg, Hamburg, Germany

Franqueville C (1971) Macroplancton profond (Invertebrés) de la Mediterranée nord-occidentale. Tethys 3:11-55

Galil B, Goren M (1994) The deepsea levantine fauna. New records and rare occurences. Senkenbergiana Marit 25:41-52

Gibson DM, Paffenhöfer G-A (2002) Feeding and growth rates of the doliolid, Dolioletta gegenbauri Uljanin (Tunicata, Thaliacea). J Plankton Res 22:1485-1500

Godeaux J (1961) L'oozooid de Doliolum nationalis Borgert. Bull Soc R Sci Liège 30:5-10

Godeaux J (1987) Thaliacés récoltés en Méditerranée centrale par le N.O. Atlantis II (Woods Hole). Bull Soc R Sci Liège 56:107-123

Godeaux J (1998) The relationships and systematics of the Thaliacea with keys for identification. In: Bone Q (ed) The Biology of pelagic Tunicates. Oxford University Press, Oxford, pp 273-294

Godeaux J (1999) The thaliaceans, a group of animals refractory to Lessepsian migration: an updated survey of their populations in the Levantine Basin and the Red Sea. Isr J Zool 45:91-100

Greze VN (1963) Zooplankton of the Ionian Sea. Resul'taty issledovanii no programmie mezhdunarodnovo geofizitcheskovo goda. Okeanologitcheskie Issled 9:42-59 (in Russian)

Kashkina AA (1978) Area of concentration and abundances of salps in the Atlantic Ocean. Soviet J Mar Biol 4:643-648

Kiortsis V (1974) Quelques considérations sur l'écologie du zooplancton en mer Egée. Répartition géographique et variations saisonnières. Rapp Comm Int. Mer Médit 22:139-141

Klein B, Roether W, Manca BB, Bregant D, Beitzel V, Kovacevic V, Luchetta A (1999) The large deep-water transient in the Eastern Mediterranean. Deep-Sea Res I 46:371-414

Koppelmann R, Weikert H (2007) Spatial and temporal distribution patterns of deep-sea mesozooplankton in the eastern Mediterranean-indications of a climatically induced shift? Mar Ecol 28:1-17

Kott P (1953) Modified whirling apparatus for the subsampling of zooplankton. Aust J Mar Freshw Res 4:387-393

Kremer P, Madin LP (1992) Particle retention efficiency of salps. J Plankton Res 14:1009-1015

Krom MD, Brenner S, Kress N, Neori A, Gordon LI (1992) Nutrient dynamics and new production in a warm core eddy from the Eastern Mediterranean. Deep-Sea Res 39:467-480

Lenz J, Auf Dem Venne H, Detmer A, Fritsch, P, Junghans U, Kirsch I, Lütkebohle T, Turmewitsch R (1994) Primary production and microbiology loop in the mixed surface layer. In: Hieke W, Halbach P, Türkay M, Weikert H (eds) Mittelmeer 1993, Cruise no. 25, 12 May-20 August 1993. METEOR-Berichte 94-3. Universität Hamburg, Hamburg, Germany, pp 81-89

Licandro P, Ibañez F, Etienne M (2006) Long-term fluctuations (1974-1999) of the salps Thalia democratica and Salpa fusiformis in the northwestern Mediterranean Sea: Relationship with hydroclimatic variability. Limnol Oceanogr 51:1832-1848

Madin LP, Deibel D (1998) Feeding and energetics of Thaliacea. In: Bone Q (ed) The Biology of pelagic Tunicates. Oxford University Press, Oxford, pp 80-105

Mazzocchi MG, Christou E, Fragopoulu N, Siokou-Frangou I (1996) Mesozooplankton distribution from Sicily to Cyprus (Eastern Mediterranean): I. General aspects. Oceanol Acta 20:521-535

Menard F, Fromentin JM, Dallot S (1997) Temporal fluctuations of doliolid abundance in the bay of Villefranche-sur-Mer (Northwestern Mediterranean Sea) from 1967 to 1990. Oceanol Acta 20:733-742

Morris RJ, Bone Q, Head R, Braconnot JC, Nival P (1988) Role of salps in the flux of organic matter to the bottom of the Ligurian Sea. Mar Biol 97:237-241

Özsoy E, Hecht A, Ünlüata Ü (1989) Circulation and hydrography of the Levantine Basin. Results of POEM coordinated experiments 1985-1986. Prog Oceanogr 22:125-170

Paffenhöfer G-A, Gibson DM (1999) Determination of generation time and asexual fecundity of doliolids (Tunicata, Thaliacea). Oceanol Acta 21:1183-1189

Paffenhöfer G-A, Stewart TB, Youngbluth MJ, Bailey TG (1991) High-resolution vertical profiles of pelagic tunicates. J Plankton Res 13:971-981

Paffenhöfer G-A, Atkinson LP, Lee TN, Verity PG, Bulluck LR (1995) Distribution and abundance of thaliaceans and copepods off the Southeastern U. S. during winter. Cont Shelf Res 15:255280

Redfield AC, Ketchum F, Richards FA (1963) The influence of organisms on the composition of seawater. In: Hill MN (ed) The sea, ideas and observations, vol 2. Interscience, New York, pp 26-77

Roether W, Klein B, Manca BB, Theocharis A, Kioroglou S (2007) Transient Eastern Mediterranean deep waters in response to the massive dense-water output of the Aegean Sea in the 1990s. Prog Oceanogr 74:540-571

Sachs L (1999) Angewandte Statistik: Anwendung statistischer Methoden, 9th edn. Springer, Berlin, Germany

Salihoglu I, Saydam C, Bastürk Ö, Yilmaz K, Göcmen D, Hatipoglu E, Yilmaz A (1990) Transport and distribution of nutrients and chlorophyll-a by mesoscale eddies in the northeastern Mediterranean. Mar Chem 29:375-390

Schrope M (2007) Treaty caution on plankton plans. Nature 447:1039

Scotto di Carlo B, Ianora A (1983) Standing stocks and species composition of Mediterranean zooplankton. In: Carrada D, Hopkins T, Leftié Lj, Morcos S (eds) Quantitative analysis and simulation of Mediterranean coastal ecosystems: the Gulf of Naples, a case study. Unesco reports in marine sciences 20. UNESCO, Paris, pp 59-69

Silver MW, Bruland KW (1992) Differential feeding and fecal pellet composition of salps and pteropods, and the possible origin of the deep-water flora and olive-green cells. Mar Biol 62:263-273

Siokou-Frangou I, Papathanassiou E (1989) Aspects du zooplancton côtier de l'Ile de Rhodes (mer Egée). Vie Milieu 39:77-85

Siokou-Frangou I, Gotsis-Skretas O, Christou ED, Pagou K (1999) Plankton characteristics in the Aegean, Ionian and NW Levantine Seas. In: Malanotte-Rizzoli P, Eremeev VN (eds) The eastern Mediterranean as a Laboratory for the Assessment of Contrasting Ecosystems. Kluwer Academic Publishers, Dordrecht, The Netherlands, pp 205-223 
Small LF, Fowler SW, Unluv MY (1979) Sinking rates of natural fecal pellets. Mar Biol 51:223-241

van Soest RWM (1998) The cladistic biogeography of salps and pyrosomas. In: Bone Q (ed) The Biology of pelagic Tunicates. University Press, Oxford, pp 231-249

Steedman HF (1976) General and applied data on formaldehyde fixation and preservation of marine zooplankton. In: Steedman HF (ed) Zooplankton fixation and preservation. Monographs on oceanographic methodology 4. UNESCO, Paris, pp 103-154

Tew KS, Lo W-T (2005) Distribution of Thalicea in SW Taiwan coastal water in 1997, with special reference to Doliolum denticulatum, Thalia democratica and T. orientalis. Mar Ecol Prog Ser 292:181-193

Turley CM, Bianchi M, Christaki U, Conan P, Harris JRW, Psarra S, Ruddy G, Stutt ED, Tselepides A, van Wambeke F (2000) Relationship between primary producers and bacteria in an oligotrophic sea-the Mediterranean and biogeochemical implications. Mar Ecol Prog Ser 193:11-18

Vargas CA, Madin LP (2004) Zooplankton feeding ecology: Clearance and ingestion rates of the salps Thalia democratica, Cyclosalpa affinis and Salpa cylindrica on naturally occurring particles in the Mid-Atlantic Bight. J Plankton Res 26:827-833

Weikert H (1994) Structure and dynamics of plankton and micronekton. Gross features of the examined sites. In: Hieke W, Halbach P, Türkay M, Weikert H (eds) Mittelmeer 1993, Cruise no. 25, 12 May-20 August 1993. METEOR-Berichte 94-3, Universität Hamburg, Hamburg, Germany

Weikert H (1995) Strong variability of bathypelagic zooplankton at a site in the Levantine Sea-a signal of seasonality in a lowlatitude deep-sea? Rapp Comm Int Mer Médit 34:218

Weikert H, Trinkaus S (1990) Vertical mesozooplankton abundance and distribution in the deep Eastern Mediterranean Sea SE of Crete. J Plankton Res 12:601-628

Weikert H, Koppelmann R, Wiegratz S (2001) Evidence of episodic changes in deep-sea mesozooplankton abundance and composition in the Levantine Sea (Eastern Mediterranean). J Mar Syst 30:221-239

Wiebe PH, Madin LP, Haury LR, Harbison GR, Philbin LM (1979) Diel vertical migration by Salpa aspera and its potential for large-scale particulate organic matter transport to the deep-sea. Mar Biol 53:249-255

Wiebe PH, Morton AW, Bradley AM, Backus RH, Craddock JE, Barber V, Cowles TJ, Flierl GR (1985) New developments in the MOCNESS, an apparatus for sampling zooplankton and micronekton. Mar Biol 87:313-323

Yilmaz A, Lenz J, Detmer A, Fritsche P, Kriest I, Lütkebohle T, Sell H, Auf dem Venne H (1994) Hydrography. In: Hieke W, Halbach P, Türkay M, Weikert H (eds) Mittelmeer 1993, Cruise no. 25, 12 May-20 August 1993. METEOR-Berichte 94-3, Universität Hamburg, Hamburg, Germany, pp 96-106 